\title{
Development of Information Systems Models Management for Students
}

\author{
Subaiki Ikhwan ${ }^{1, a^{*}}$, Mukhneri Mukhtar ${ }^{1, b}$, and Mochamad Wahyudi1,c \\ ${ }^{1}$ Educational Management, Post Graduate Program, Universitas Negeri Jakarta, Indonesia \\ a subaikiikhwan@stai-nuruliman.ac.id; b mukhnerimukhtar@unj.ac.id; c wahyudi@nusamandiri.ac.id \\ ${ }^{*}$ Corresponding Author \\ Whatsapp number: [08567204464]
}

How to Cite : Ikhwan, S., Mukhtar, M., Wahyudi, M. (2019). Development of Information Systems Models Management for Students. International Journal for Educational and Vocational Studies, 1 (7), 724-727

\section{ARTICLE HISTORY}

Received: 25 July 2019

Revised: 13 August 2019

Accepted: 17 October 2019

\section{KEYWORDS}

Student Management;

Information Systems;

Spiral Model;

Feasibility Test;

\section{ABSTRACT}

Student management is an important part that must be considered by schools. The government has made standardized rules for how schools can manage students so that they are in accordance with National Education Standards. Student management activities start from registration, until student services that have been arranged neatly, may not run optimally, if schools are still manual in tidying student data collection. By him the role of student management information systems is very important for every school to have. This study aims to determine how schools can create student management information systems that are feasible and effective.

This is an open access article under the CC-BY-SA license.

\section{INTRODUCTION}

School is an institution that accepts students as input and how to manage it with various existing components to become outputs that are needed in the community. Schools must refer to all aspects contained in Permendiknas No. 19 of 2007 concerning the management of the education system, starting from how schools plan, implement, supervise and make evaluations (Thomas \& Asselin, 2018; Sengkey et al., 2019; Suhada et al., 2019).

In the stages of the process, schools are required to perfect education standards including the standards of educators and teaching staff, curriculum, finance, facilities and infrastructure, as well as management. Of course, it was made so that the Government can easily assess how an educational institution is managing its education well (García Redondo, 2016). In addition to achieving national education goals, the Government to achieve also strivesequitable distribution of education at various levels, from various locations both in cities and villages, as targeted.

The management aspects of students certainly become quite urgent. Students as objects that get treatment from the environment and various other instruments are the outcomes expected by the community. The government regulates how schools plan, recruit students, placement, guidance, administration, evaluation and provide services to students (Ochwo, 2018; Ikawati et al., 2019).

Student management activities start from registration, until student services that have been prepared carefully, do not always produce results as expected. Although in the stages of the function management, the school principal has tried to do the directing well and motivates optimally to achieve educational goals, it is not yet perfect, if the school is still manual in tidying the student database. Therefore, the role of management information systems for students is very important for every school. Schools in implementing a management information system should carry out a series of activities, namely; capturing, verifying, classifying, summarizing, calculating, storing, retrieving, reproducing and disseminating (Paragina, Paragina, Jipa, Savu, \& Dumitrescu, 2011).

This study aims to determine how the feasibility and effectiveness of the information system model of students using the spiral model.

\section{Model Development}

Model as a simplification of forms, processes, physical phenomena or complex ideas. Because the reality that is too broad can be described and complexity simplified into unique and specific situations. Ideas or manifestations of something so broad, by the designer with the ability and 
creativity, are simplified into patterns interesting or specific images.

Development is the process, way, and implementation of developing. then the development of the model in this study is a process of thought patterns in the form of designs consisting of interrelated components and represented in graphical or narrative form that is used as a reference guide to realizing a concept that is developed in a measurable manner (Holland, 2018; Gartika et al., 2019). Development of the model at least there are components of needs analysis, the purpose of model development, systematic model development, and evaluation of the development of the model.

\section{Spiral Model}

The spiral model originally proposed by Boehm is an evolutionary software process model that assembles the iterative nature of prototypes using control and systematic aspects of linear sequential models. Iterative models are characterized by behaviours that allow developers to develop more versions of the software to gradually complete. Stages of the spiral model, namely communication to users, planning, risk analysis, engineering, construction, and evaluation (Sommerville, 2016).

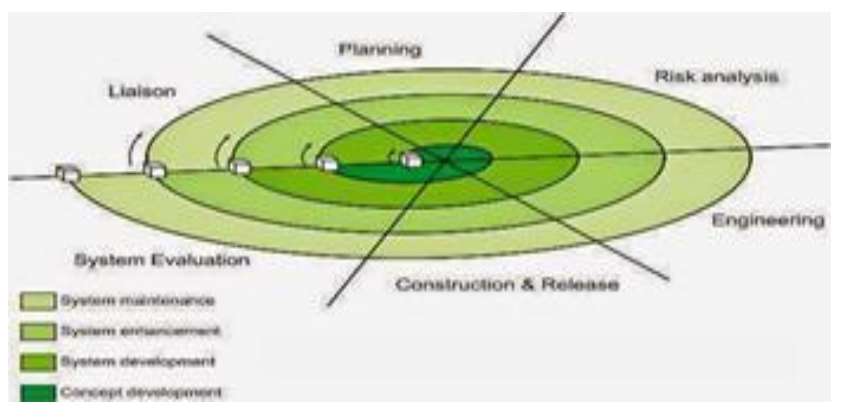

Figure 1. Model SDLC System with Spiral

The stages can be explained as follows: User communication (liaison), namely tasks to establish communication between users and the needs of the needs desired by the user. Planning tasks that are to define resources, timeliness, and project information other relevant. Risk analysis that the tasks required to assess risks and technical management. Engineering that is the task needed to build one or more representations of the application. Construction that the tasks required to construct, test, install, and provide service to the user. Evaluation. namely, tasks to get feedback from customers (Pressman, 2017).

\section{Management Information System}

An information system is a collection of information components that are collected, processed, prepared and distributed to support organizational decision making and control. Information is collected and then management is taken into consideration by managers in the organizational decision-making process (Ezell et al., 2019).

The information system that has been managed can be in the form of reports and can be displayed to managers in managing the organization. The information that is managed should be complete, accurate and up to date. Because changes in the environmental organizations both externally and internally so quickly affect organizational performance. Information management is an appropriate strategy in dealing with organizational change and transformation, so that needed complete, accurate and up-to-date information is. Management information systems function to develop, implement and manage information technology, software and portfolio applications that are used to support the progress of the organization. system management Information is managing information using information technology (website, digital, e-mail, software, etc.), with the use of information technology, it can accelerate and facilitate the (latest) update of information in organizational development (Akaranga, 2016).

\section{METHODS}

The approach in this study uses a research and development approach. The method used is the system development life cycle or better known as SDLC is a methodology generalised to develop information systems. SDLC consists of several phases starting from the planning, analysis, design, development, testing, implementation and system maintenance phases. The concept SDLCunderlies various types of software development models to form a framework for planning and controlling the making of information systems. The SDLC model that will be used in this study is the spiral model.

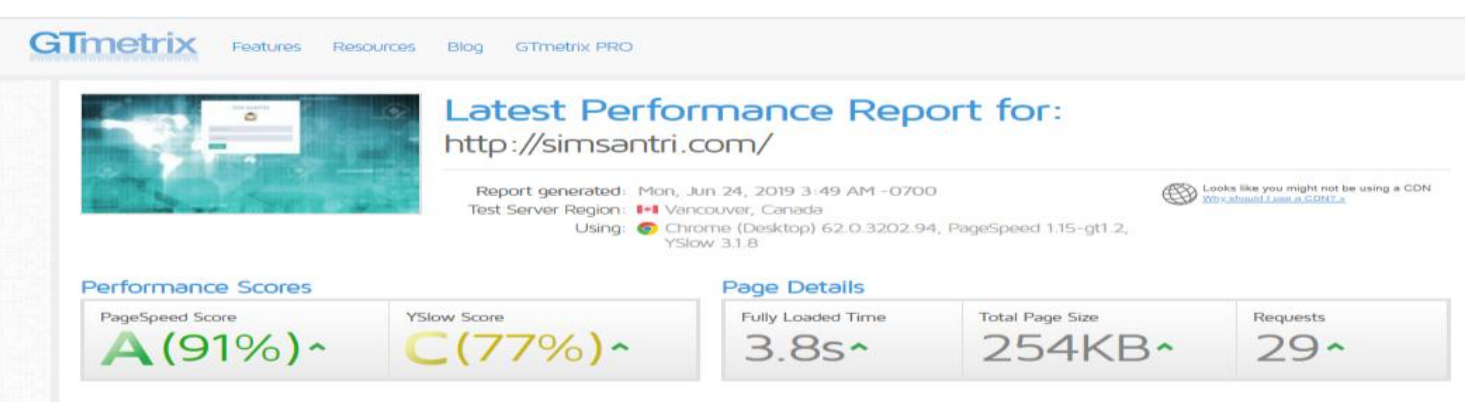

Figure 2. On the GTMetrix report home page 
The spiral model originally proposed by Boehm is an evolutionary software process model that assembles the iterative nature of the prototype using control and systematic aspects of the linear sequential model. Iterative models are characterized by behaviours that allow developers to develop more versions of the software to gradually complete. The spiral model becomes a realistic approach to the development of systems and large-scale software. Because software continues to work during the process of movement, developers and users understand and react better to risks at each level of evolution. The spiral model uses prototype 2 Fonna et al. International Journal for Educational and Vocational Studies as a risk reduction mechanism (Sommerville, 2016).

This research was conducted at the $\mathrm{Al}$ Ashriyyah Nurul Iman Islamic Boarding School Foundation, Parung Bogor. The level of education that is the object of research is the level of elementary schools (SD) and junior high schools (SMP), and senior high schools (SMA), Nurul Iman Islamic High School (STAI) for approximately 12 months from the initial stage (analysis needs, data collection) to the final stage (testing model).

\section{RESULTS AND DISCUSSION}

\subsection{Aspects of Performance Efficiency}

Testing aspects of performance efficiency using tools from GTMetrix online. The standard values given are from A to $\mathrm{F}$ with an average percentage of $79 \%$ seen from the PageSpeed Score and rules YSlow Score.

Figure 2. on the GTMetrix report home page explains the measurement results with PageSpeed of $91 \%$ grade A, YSlow $77 \%$ grade $\mathrm{A}$, the response time of $3.8 \mathrm{~s}$, the total page size of $254 \mathrm{~KB}$ and 29 requests

\subsection{Aspect of Usability}

Usability testing using the USE Questionnaire has 10 statements as measured by a Likert scale. The USE Questionnaire Questionnaire was given to 30 respondents consisting of Principals, Teachers, Parents and Students.
The recapitulation of the usability aspect test results is shown in table 1.

Table 1. Calculation of Test Scores

\begin{tabular}{cccc}
\hline Choose & Amount & Score & Amount X Score \\
\hline SS & 286 & 5 & 1430 \\
\hline S & 545 & 4 & 2180 \\
\hline KS & 67 & 3 & 201 \\
\hline TS & 0 & 2 & 0 \\
\hline STS & 0 & 1 & 0 \\
\hline
\end{tabular}

Usability: Maximum score $=$ number of respondents $\mathrm{x}$ number of questionnaires $\mathrm{x} 5$. So the percentage is $84.69 \%$. The results of the percentage of usability aspects testing are $84.69 \%$ which is then converted to a qualitative scale which means "Very Eligible" and meets the standard aspects of usability.

\subsection{Aspects of Security}

In testing security using the application Acunetix Web Vulnerability Scanner 10. Security testing on information systems reports student learning outcomes to have a level of vulnerability to attacks that are at level 1 . Vulnerability to level 1 or low-level attacks indicates the vulnerability comes from a lack of encryption traffic data or directory path disclosure (Acunetix, 2013).

Based on the test results shown it can be concluded that the management information system of students has met the security standards because the level of a vulnerability is below level 2 or medium.

\subsection{Aspects of Reliability}

In reliability testing performed with the WAPT 9.3 tool, a scenario with 20 virtual users created in 10 minutes was. Tests for the admin profile show $100 \%$ success results, with sessions 20, pages 2430 and 3179 hits as described in Figure 3.

\begin{tabular}{|c|c|c|c|c|c|c|c|c|c|c|}
\hline Profile & $\begin{array}{l}\text { Successful } \\
\text { sessions }\end{array}$ & $\begin{array}{l}\text { Faled } \\
\text { sessions }\end{array}$ & $\begin{array}{l}\text { Successful } \\
\text { pages }\end{array}$ & $\begin{array}{l}\text { Failed } \\
\text { pages }\end{array}$ & $\begin{array}{l}\text { Successful } \\
\text { hits }\end{array}$ & $\begin{array}{l}\text { Faled } \\
\text { hits }\end{array}$ & $\begin{array}{l}\text { Other } \\
\text { errors }\end{array}$ & $\begin{array}{l}\text { Total } \\
\text { KBytes } \\
\text { sent }\end{array}$ & $\begin{array}{l}\text { Total KBytes } \\
\text { received }\end{array}$ & $\begin{array}{l}\text { Avg response time, sec } \\
\text { (with page elements) }\end{array}$ \\
\hline Admin & 20 & 0 & 1792 & $\theta$ & 2487 & 0 & 0 & 1493. & 57314 & $0.17(0.17)$ \\
\hline
\end{tabular}

\begin{tabular}{|c|c|c|c|c|c|c|c|c|c|c|}
\hline \multicolumn{11}{|c|}{ Number of active users } \\
\hline Profile & $\begin{array}{l}0: 00: 00 \\
0: 01: 00\end{array}$ & $\begin{array}{l}0101=00 \\
0: 02=00\end{array}$ & $\begin{array}{l}0: 02: 00- \\
0 ; 03: 00\end{array}$ & $\begin{array}{l}0: 03: 00= \\
0: 04: 00\end{array}$ & $\begin{array}{l}0: 04: 00- \\
0: 05: 00\end{array}$ & $\begin{array}{l}0105: 00 \\
0: 06: 00\end{array}$ & $\begin{array}{l}0=06: 00- \\
0: 07: 00\end{array}$ & $\begin{array}{l}0: 07: 00 \\
0: 00: 00\end{array}$ & $\begin{array}{l}0: 08100 . \\
0 ; 09: 00\end{array}$ & $\begin{array}{l}0: 09: 00 \\
0: 10: 00\end{array}$ \\
\hline Admin & 20 & 20 & 20 & 20 & 20 & 20 & 20 & 20 & 20 & 20 \\
\hline Total & 20 & 20 & 20 & 20 & 20 & 20 & 20 & 20 & 20 & 20 \\
\hline
\end{tabular}

Figure 3. Aspects of Reliability

\subsection{Aspects of Maintainability}

Testing the maintainability aspect is carried out using the
Semantic Design tool to measure Halstead Volume, Lines of Code and Cyclomatic Complexity values which are then used in calculating the values Maintainability Index. The 
test results maintainability of on the module. the controller data analysis was obtained from the average results of the calculation of the two values of maintainability index all existing modules.

\section{CONCLUSION}

The study concluded that the development of management information system model learners tested through aspect Efficiency Performance, aspects, Usability aspects, security aspects of Reliability and Maintainability aspects as feasible and effective.

\section{REFERENCES}

Acunetix. (2013). Web Vulnerability Scanner v8 User Manual. (February).

Akaranga, S. I. B. K. (2016). The hermeneutics of education management Information Systems for Kitinga primary school in Mwingi central, Kenya. Journal of Education and Practice, 7(35), 36-40.

Ezell, J. D., Lending, D., Dillon, T. W., May, J., Hurney, C. A., Fulcher, K. H., ... Dillon, T. W. (2019). Information Systems Education Developing Measurable Cross-Departmental Learning Objectives for Requirements Elicitation in an Information Systems Curriculum Developing Measurable Cross-Departmental Learning Objectives for Requirements Elicitation in an In. 30 (April 2018).

García Redondo, E. (2016). La gobernanza en las Instituciones de enseñanza en Portugal. Journal of New Approaches in Educational Research, 6(1), 17-22. https://doi.org/10.7821/naer.2016.1.156.

Gartika, E., Rahayu, W., \& Utomo, E. (2019). Development of Interactive Mathematics Multimedia Teaching Materials for Building Space in Class V Primary Schools. International Journal for Educational and Vocational Studies, 1(5), 467-472.

Holland, B. (2018). A Workforce Development Systems Model for Unemployed Job Seekers. Journal of Adult and Continuing Education, 21(2), 55-76. https://doi.org/10.7227/jace.21.2.5

Ikawati, H. D., Majid, I. A., \& Anwar, Z. (2019). Effectiveness of the Superitem Learning Model on Students Learning Achievements. International Journal for Educational and Vocational Studies, 1(3), 184-188.

Ochwo, D. (2018). Efficacy of information and communication technology in digitalized students' records management in universities in Eastern Uganda. African Educational Research Journal, 6(2), 99-106. https://doi.org/10.30918/aerj.62.18.009

Paragina, S., Paragina, F., Jipa, A., Savu, T., \& Dumitrescu, A. (2011). The Moodle course management system and its e-learners' needs. Procedia - Social and Behavioral Sciences, 15, 1226-1230. https://doi.org/https://doi.org/10.1016/j.sbspro.2011.03.2 67

Pressman, R. S. (2017). Software Engineering A Practitioner's Approach. New York: Mc Graw Hill Education.

Sengkey, D. F., Paturusi, S. D. E., Sambul, A. M., \& Gozali, C. T. (2019). A Survey on Students' Interests toward On-line Learning Media Choices (A Case Study from the Operations Research Course in the Department of Electrical Engineering, UNSRAT). International Journal for Educational and Vocational Studies, 1(2). 146-152.

Sommerville, I. (2016). Software Engineering (10th ed.). England: Pearson.

Suhada, H., Nulhakim, L., Sudarto, F., \& Kristiadi, D. P. (2019). Blended Learning Development In Islamic Religious Education Lessons Make Use of Web and Android. International Journal for Educational and Vocational Studies, 1(5), 428-433.

Thomas, L. J., \& Asselin, M. (2018). Promoting resilience among nursing students in clinical education. Nurse Education in Practice, 28(Supplement C), 231-234. https://doi.org/https://doi.org/10.1016/j.nepr.2017.10.001 